\title{
Kekuatan Mengikat Keputusan Arbitrase ICSID Dalam Penyelesain Sengketa Penanaman Modal
}

\author{
Ida Ayu Gde Wulan Purnamasari1
}

${ }^{1}$ Magister Kenotariatan Unversitas Udayana, E-mail : wulanpurnama.tvribali@gmail.com

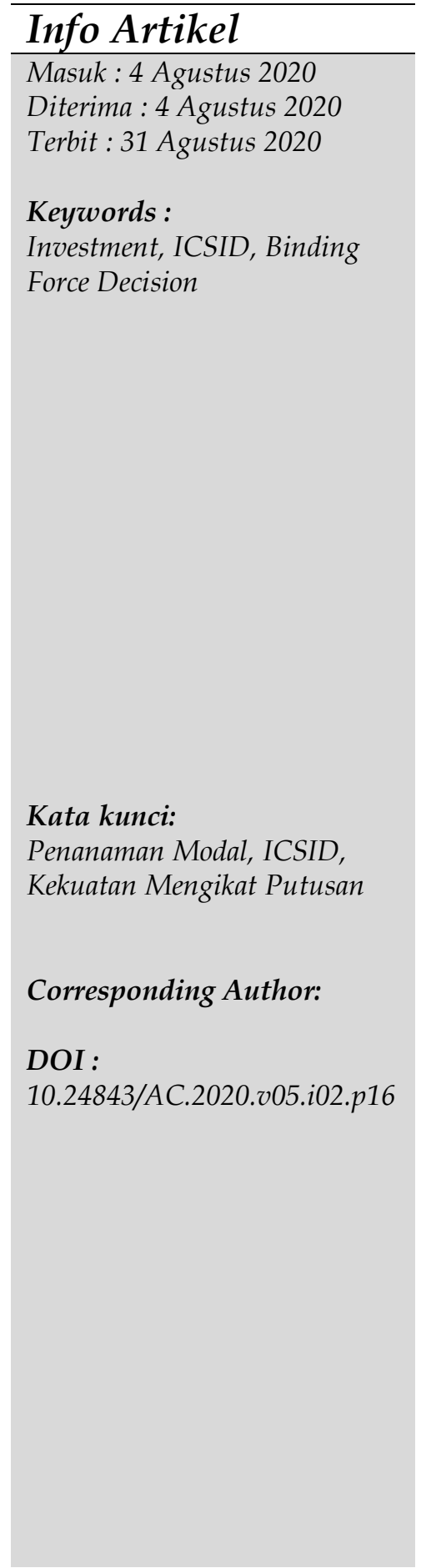

\begin{abstract}
Foreign investment is the things that gives influence to the development of domestic countries in the world. Based on that, it is really interesting to take a study for the concept of foreign investment in Indonesia and regarding the binding strength of the ICSID Arbitration Institute in resolving investment disputes between Churcill Mining and the Government of Indonesia. This Study using a normative method with secondary data consisting of primary legal materials, secondary legal materials, and tertiary legal materials. The collected data then analyzed using descriptive methods. The results of this study that foreign investment is doing business by investing in the territory of Indonesia which is carried out either by individuals of foreign citizens, foreign business entities, and/or foreign governments. Furthermore, it is related to the ICSID decision in the disputes between Churchill Mining and the Government of Indonesia which is final and binding so that is must be implemented because of the parties. ICSID Arbitration conducts hearings according to the rules of international law as specified in the ICSID Convention, regulations and rules established for the proceedings of the trial.
\end{abstract}

\footnotetext{
Abstrak

Penanaman modal asing adalah hal yang sangat memberikan pengaruh terhadap pembangunan dalam negeri negara-negara di dunia. Berdasarkan hal tersebut menjadi menarik untuk dikaji konsep penanaman modal asing di Indonesia dan mengenai kekuatan mengikat keputusan lembaga Arbitrase ICSID dalam penyelesaian sengketa penanaman modal antara Churchill Mining dan Pemerintah Indonesia. Penelitian ini menggunakan metode normatif dengan menggunakan data sekunder yang terdiri atas bahan hukum primer, bahan hukum sekunder, dan bahan hukum tersier. Data yang telah terkumpul kemudian dianalisis menggunakan metode deskriptif. Penelitian ini menunjukkan hasil bahwa penanaman modal asing adalah melakukan usaha dengan menanamkan modal di wilayah Indonesia yang dilakukan baik oleh perorangan warga negara asing, badan usaha asing, dan/atau pemerintah asing. Selanjutnya terkait dengan putusan ICSID dalam sengketa Churchill Mining dan Pemerintah Indonesia bersifat final dan mengikat sehingga harus dapat dilaksanakan karena para pihak. Arbitrase ICSID melaksanakan persidangan menurut aturan hukum internasional sebagaimana yang ditentukan dalam Konvensi ICSID, regulasi serta aturan yang dibentuk untuk proses pelaksanaan persidangan.
} 


\section{Pendahuluan}

Penanaman modal asing menjadi hal yang berpengaruh untuk pembangunan dalam negeri, baik dalam hal produksi, perekonomian, peluang kerja, dan lain sebagainya yang diharapkan dapat berperan untuk meningkatkan taraf dan pembangunan kehidupan ekonomi masyarakat. Bagi negara-negara tuan rumah, tindakan penanaman modal asing menjadi hal yang sangat menguntungkan karena dengan hal tersebut negara yang menerima penanaman modal asing dapat menjamin dan mengalihkan modal yang terdapat di dalam negeri untuk kepentingan masyarakat. ${ }^{1}$

Transaksi yang terkait dengan penanaman modal atau investasi biasanya akan dituangkan dalam kontrak yang berisi tentang hal-hal yang telah disepakati para pihak seperti siapa saja yang melakukan kerjasama, bentuk kerjasama yang dilakukan, waktu kerjasama, jalur penyelesaian sengketa dan lain sebagainya. ${ }^{2}$ Dalam hal penyelesaian sengketa biasanya ada kesepakatan dari kedua belah pihak untuk menentukan forum sengketa baik cara penyelesaian sengketa maupun tempat untuk penyelesaian sengketa antara para pihak di dalam kontrak. ${ }^{3}$ Para pelaku usaha lebih sering memilih Alternatif Penyelesaian Sengketa (ADR) karena proses penyelesaiannya yang lebih efektif dan adil. Penyelesaian sengketa melalui ADR memiliki berbagai macam pilihan, salah satunya yaitu arbitrase baik arbitrase nasional maupun international. ${ }^{4}$

Salah satu lembaga penyelesaian sengketa penanaman modal yang melibatkan perusahaan asing atau penanaman modal asing di Indonesia adalah lembaga Arbitrase ICSID atau The International Centre for the Settlement of Investment Disputes. ICSID memiliki yurisdiksi untuk menyelesaikan sengketa yang muncul dari kegiatan penanaman modal yang dilakukan oleh negara-negara peserta Konvensi ICSID.

Terbentuknya Konvensi ICSID dilatarbelakangi oleh kesadaran bahwa perlu adanya kerjasama dalam hal penanaman modal dan pembangunan ekonomi internasional. Kadangkala penanaman modal atau kerjasama internasional menimbulkan suatu sengketa antara penanam modal dengan negara penerima modal. ${ }^{5}$ Konvensi ICSID bertujuan agar adanya aturan hukum yang jelas dan dapat dijadikan dasar dalam penyelesaian sengketa penanaman modal baik melalui mekanisme konsiliasi atau

1 M. Somarajah, 1994, The International Law on Foreign Investment, Cambridge U.P, Cambridge, hlm. 5.

2 Aldo Rico Geraldi, "Kompetensi Arbitrase Internasional Dan Pengadilan Nasional Terkait Penyelesaian Sengketa Penanaman Modal Asing", Jurnal Advokasi FH UNMAS, Vol. 7, No. 2, 2017, hlm. 150.

3 Syahmin AK, 2006, Hukum Kontrak Internasional, PT RajaGrafindo Persada, Jakarta, hlm. 2.

4 Arbitrase adalah Suatu alternative penyelesaian sengketa melalui pihak ketiga (badan arbitrase) yang ditunjuk dan disepakati para pihak (negara) secara sukarela memutus sengketa yang bukan bersifat perdata dan putusannya bersifat final dan mengikat. Huala Adolf, 2012, Hukum Penyelesaian Sengketa Internasional, Sinar Grafika, Jakarta, hlm. 39-40.

5 Paragraf 1 dan 2 Pembukaan Konvensi ICSID (Convention on the Settlement of Investment Dispute Between States and National of Other States). 
arbitrase serta untuk melindungi dan mendorong arus modal antar negara. ${ }^{6}$ Konvensi ICSID mulai berlaku di Indonesia pada tanggal 28 Oktober 1968 setelah penandatanganan pada tanggal 16 Februari 1968 dan ratifikasi pada tanggal 28 September 1968. Berlakunya Konvensi ICSID memberikan pengaruh terhadap penyelesaian sengketa penanaman modal antara Pemerintah Indonesia dengan pihak asing yang dapat diselesaikan melalui ICSID. ${ }^{7}$

ICSID menjadi lembaga arbitrase yang menyelesaikan sengketa antara Churchill Mining dan Pemerintah Indonesia. Sengketa tersebut diselesaikan oleh ICSID karena adanya gugatan yang diajukan terkait dengan dicabutnya izin pertambangan yang dimiliki oleh Ridlatama Group di Kalimantan Timur dengan luas area sekitar 35 ribu hektare oleh Pemerintah Kabupaten Kutai Timur. ${ }^{8}$ Hal tersebut dilakukan karena adanya audit BPK yang menemukan adanya lima Kuasa Pertambangan palsu yang diterbitkan tahun 2006-2008. ${ }^{9}$

ICSID kemudian mengeluarkan putusan mengenai yurisdiksi yang dimiliki dalam memeriksa gugatan Churchill Mining yang ditujukan kepada Pemerintah Indonesia tanggal 24 Februari 2014..$^{10}$ Keputusan ICSID menyatakan bahwa memiliki wewenang dalam memeriksa gugatan yang diajukan berdasarkan interpretasi perjanjian Bilateral Investment Treaty (BIT) yang dibuat oleh Pemerintah Indonesia dengan Inggris mengenai forum penyelesaian sengketa.

\section{Metode Penelitian}

Tulisan ini adalah hasil dari sebuah penelitian yang menggunakan metode hukum normatif dengan mengkaji aturan-aturan hukum yang terkait dengan permasalahan dalam penelitian ini ${ }^{11}$ Pengumpulan data dilakukan dengan menggunakan metode studi kepustakaan terkait bahan hukum primer, bahan hukum sekunder, dan bahan hukum tersier. Data yang terkumpul kemudian dianalisis menggunakan metode deskriptif.

6 Huala Adolf, 2002, Arbitase Komersial Internasional, RajaGrafindo Persada, Jakarta, hlm. 37-38.

7 Aldo Rico Geraldi, "Penyelesaian Sengketa Investasi Melalui International Centre For Settlement Of Investment Dispute (Studi Kasus Pemerintah Indonesia Vs Churchill Mining)", Tanjungpura Law Journal, Vol. 1, Issue 2, 2017, hlm. 95.

8 Churchill Mining mengakuisisi 75\% perusahaan Ridlatama Group. Lihat juga Artikel, Churchill vs Indonesia: Permintaan Perlindungan oleh Churchill Ditolak, 24 Desember 2014, URL : http://www.tambang.co.id/churchill-vs-indonesia-permintaan-perlindungan-oleh-churchill-ditolak2516/, diakses pada tanggal 2 Januari 2019.

9 Artikel Antara News, Indonesia siapkan data pendukung hadapi gugatan, 15 Juni 2012, URL :http://www.antaranews.com/berita/316344/indonesia-siapkan-data-pendukung-hadapi-gugatanchurchill, diakses pada tanggal 2 Januari 2019.

10 Rista Rama Dhany, Digugat Churchill Rp 20 T, Pemerintah RI Percaya Diri Menang, 26 Februari 2014, URL : http://finance.detik.com/read/2014/02/26/183143/2509500/1034/digugat-churchill-rp-20t-pemerintah-ri-percaya-diri-menang, diakses pada tanggal 2 Januari 2019.

11 Mukti Fajar dan Yulianto Achmad, 2010, Dualisme Penelitian Hukum Normatif \& Empiris, Pustaka Pelajar, Yogyakarta, hlm. 34. 


\section{Hasil Dan Analisis}

\subsection{Konsep Penanaman Modal Asing di Indonesia}

Negara yang sedang berkembang biasanya melakukan penanaman modal asing yang berkaitan dengan persoalan ekonomi, politis dan hukum. Aspek-aspek ekonomi, politis dan hukum tersebut memiliki pengaruh yang besar terhadap masuknya dan efektivitas operasional modal asing antar negara, terutama negara berkembang. Hal tersebut dikarenakan masuknya modal asing ke negara berkembang merupakan bagian rencana pembangunan ekonomi negara tersebut. ${ }^{12}$

Undang-Undang Nomor 25 Tahun 2007 tentang Penanaman Modal memberikan pengertian terkait dengan modal yang merupakan aset baik berbentuk uang atau bentuk lainnya yang memiliki nilai ekonomis. ${ }^{13}$ Terkait modal asing didefinisikan sebagai suatu modal yang dimiliki baik oleh perorangan warga negara asing, badan usaha dan badan hukum asing, serta badan hukum Indonesia yang modalnya sebagian atau seluruhnya dimiliki oleh pihak asing. ${ }^{14}$

Perusahaan multinasional memainkan peranan yang penting terkait penanaman modal asing yang dilakukan oleh negara maju kepada negara berkembang. Penanaman modal asing yang dilakukan oleh perusahaan multinasional merupakan strategi yang tepat dalam meningkatkan pembangunan ekonomi jika dibandingan dengan melakukan pembelian lisensi atau pinjaman luar negeri dan lain sebagainya yang dilakukan oleh perusahaan dalam negeri. ${ }^{15}$ Perusahaan multinasional biasanya melakukan kegiatan penanaman modal dengan cara usaha patungan, mendirikan cabang atau anak perusahaan, dan memiliki afiliasi terbesar yang tersebar di berbagai negara.

Penanaman modal asing bertujuan untuk mendapatkan laba melalui penciptaan suatu produksi atau jasa yang dilakukan pihak asing disuatu negara. Penanaman modal memiliki pengertian sebagai segala kegiatan penanaman modal dari dalam negeri atau modal asing yang bertujuan untuk melakukan berbagai usaha di wilayah Indonesia. ${ }^{16}$ Terkait dengan penanaman modal asing didefinisikan sebagai penanaman modal yang dilakukan oleh pihak asing dengan modal sepenuhnya atau berpatungan dengan pemilik modal dalam negeri untuk melakukan usaha di wilayah Indonesia. ${ }^{17}$

Penanaman modal asing di wilayah Indonesia dapat dilakukan oleh warga negara asing baik orang perorang maupun kelompok, badan usaha dan juga pemerintah asing. ${ }^{18}$ Pasal 2 Undang-Undang Nomor 25 tahun 2007 tentang Penanaman Modal

\footnotetext{
12 Sumantoro, 1984, Bunga Rampai Permasalahan Penanaman Modal dan Pasar Modal, Binacipta, Bandung, hlm. 29.

13 Lihat Pasal 1 ayat (7) Undang-Undang Nomor 25 Tahun 2007 tentang Penanaman Modal.

14 Lihat Pasal 1 ayat (8) Undang-Undang Nomor 25 Tahun 2007 tentang Penanaman Modal.

15 Albert Widjaya, 1982, Impak Kegiatan Perusahaan Multinasional Terhadap Keadaan Sosial dan Politk di Indonesia, Binacipta, Bandung, hlm. 221.

${ }^{16}$ Lihat Pasal 1 ayat (1) Undang-Undang Nomor 25 Tahun 2007 tentang Penanaman Modal.

${ }^{17}$ Lihat Pasal 1 ayat (3) Undang-Undang Nomor 25 Tahun 2007 tentang Penanaman Modal.

18 Lihat Pasal 1 ayat (6) Undang-Undang Nomor 25 Tahun 2007 tentang Penanaman Modal.
} 
menyebutkan bahwa ketentuan dalam undang-undang ini berlaku untuk penanaman modal di semua sektor. Penanaman modal yang dilakukan di semua sektor wilayah Indonesia sebagaimana yang disebutkan dalam penjelasan Pasal 2 merupakan penanaman modal langsung dan bukan merupakan penanaman modal tidak langsung atau portofolio. Namun, ketentuan tersebut tidak memberikan secara rinci terkait dengan bidang-bidang yang diperbolehkan bagi penanaman modal asing langsung di wilayah Indonesia. Terkait dengan penanaman modal asing langsung memiliki komponen yang berbeda mengenai kepemilikan modal yang merupakan penanaman modal asing di suatu negara yang melakukan pembelian saham milik perusahaan yang berada di negara lain. ${ }^{19}$

\subsection{Kekuatan Mengikat Keputusan The International Centre for the Settlement of Investment Disputes (ICSID) dalam Penyelesaian Sengketa Penanaman Modal antara Churchill Mining dan Pemerintah Indonesia}

Churcill Mining pada tanggal 22 Juni dan 26 Desember 2012 melakukan pendaftaran gugatan ke ICSID yang didasarkan pada perjanjian investasi bilateral antara Pemerintah Indonesia dengan Pemerintah Inggris. Gugatan yang dilakukan terhadap Pemerintah Indonesia didasarkan adanya tindakan yang terkait dengan ekspropriasi tidak langsung serta perlakuan yang tidak adil dan seimbang. Churchill Mining merasa dirugikan atas investasi yang telah dilakukannya di Indonesia karena pada tanggal 4 Mei 2010 terdapat empat Kuasa Pertambangan/Izin Usaha Pertambangan (KP/IUP) Eksploitasi yang dicabut oleh Pemerintah Kabupaten Kutai Timur karena adanya indikasi berdasarkan audit yang dilakukan pada tahun 2006-2008 oleh Badan Pemeriksa Keuangan (BPK). Selain itu, Menteri Kehutanan tidak pernah memberikan izin terkait dengan empat KP/IUP tersebut karena berada di kawasan hutan produksi yang mengharuskan adanya izin dari Menteri Kehutanan. ${ }^{20}$

Putusan ICSID yang dikeluarkan pada tanggal 6 Desember 2016 dengan nomor perkara ARB/12/14 (Churchill Mining PIc Vs RI) dan ARB/12/40 (Planet Mining Vs $\mathrm{RI})$, telah memenangkan gugatan yang dilakukan terhadap pemerintah Indonesia dengan nilai gugatan sebesar US\$1,31 miliar atau setara dengan Rp17 triliun. ${ }^{21}$ Putusan ICSID tersebut menolak gugatan-gugatan yang diajukan oleh Churchill Mining dengan dasar bahwa beberapa izin terkait dengan pertambangan yang dimiliki oleh pihak Churchill Mining adalah palsu atau dipalsukan, sehingga tidak memperoleh

19 Peter Malanczuk, 2008, International Law Provisions for the Protection of Foreign Investment, Public Lecture on Public International Law, State University of Padjajaran, Bandung, hlm. 4. Dalam An An Chandrawulan, 2011, Hukum Perusahaan Multinasional, Liberalisasi Hukum Perdagangan Internasional dan Hukum Penanaman Modal, P.T. Alumni, Bandung, hlm. 41.

20 Dimas Jarot Bayu, RI Menang Gugatan Arbitrase Lawan Perusahaan Tambang Inggris dan Australia, $8 \quad$ Desember 2016, URL: https://nasional.kompas.com/read/2016/12/08/21210551/ri.menang.gugatan.arbitrase.lawan.perusahaa n.tambang.inggris.dan.australia, diakses pada tanggal 2 Januari 2019.

21 Lusia Arumingtyas, Lawan Churchill Mining Indonesia Menang Gugatan Arbitrase Internasional, 10 Desemebr 2016, URL: https://www.mongabay.co.id/2016/12/10/lawan-churchill-mining-indonesiamenang-gugatan-arbitrase-internasional, diakses pada tanggal 2 Januari 2019. 
otorisasi dari Kantor Pemerintah Daerah Kutai Timur.22 Selain itu, ICSID menyatakan uji tuntas atau due dilligence yang dilakukan Churchill saat membeli izin pertambangan itu belum cukup. Namun, pengadilan tidak menemukan bukti bahwa Churchill terlibat dalam pemalsuan dokumen-dokumen tersebut. ${ }^{23}$

Indonesia menerima dana kompensasi sebesar 8,6 juta Dollar AS atau sebesar 75 persen dari total keseluruhan biaya yang telah dikeluarkan pemerintah. Di samping itu, para penggugat juga dibebankan mengganti sejumlah biaya yang dikeluarkan Pemerintah Indonesia untuk biaya administrasi sebesar 800.000 Dollar AS.

Convention on the Settlement of Investment Dispute Between States and National of Other States telah diratifikasi oleh Pemerintah Indonesia dengan Undang-Undang Nomor 5 Tahun 1968 tentang Persetujuan atas Konvensi tentang Penyelesaian Perselisihan Penanaman Modal antara Negara dengan Warga Negara Asing. ${ }^{24}$ Undang-undang tersebut menyebutkan bahwa perselisihan antara Pemerintah Indonesia dan negara lainnya terkait dengan penanaman modal diputuskan berdasarkan pada Konvensi ICSID dan mewakili Pemerintah Indonesia terkait dengan hal substitusi dalam perselisihan tersebut. ${ }^{25}$

Lembaga Arbitrase didefinisikan sebagai badan yang dipilih oleh para pihak yang bersengketa untuk dapat memberikan putusan terhadap sengketa tertentu yang menjadi yurisdiksinya serta memberikan pendapat yang bersifat mengikat terhadap suatu hubungan hukum tertentu sebelum timbulnya sengketa sebagaimana yang terdapat dalam Pasal 1 angka 8 Undang-undang No. 30 Tahun 1999 tentang Arbitrase dan Alternatif Penyelesaian Sengketa. Berdasarkan hal tersebut, maka arbitrase memiliki kemiripan dengan lembaga peradilan pada umumnya yang dapat memutuskan suatu sengketa dengan keputusan yang bersifat final dan mengikat bagi para pihak.

Arbitrase ICSID menjadi suatu arbitrase yang berbeda dengan lainnya karena ICSID merupakan suatu lembaga arbitrase internasional yang memiliki keterkaitan dengan Bank Dunia. Hal tersebut memberikan akibat penting bagi ICSID karena memiliki tujuan seperti Bank Dunia yaitu menciptakan dan meningkatkan suasana atau iklim yang saling menguntungkan dan percaya antara negara dengan pihak investor agar dapat melakukan peningkatan terhadap arus sumber kekayaan negara yang sedang berkembang dengan didasarkan pada syarat-syarat tertentu. Berdasarkan hal tersebut, maka ICSID tidak bisa hanya dipandang sebagai suatu mekanisme untuk melakukan penyelesaian sengketa, tetapi dapat memberikan peningkatan terhadap perkembangan perekonomian negara-negara yang sedang berkembang. Keterkaitan yang dimiliki

22 Hasyry Agustin, Menang Di ICSID Angkat Martabat Indonesia Di Dunia Internasional, 10 Desember 2016, URL: https://www.hukumonline.com/berita/baca/lt584abeb00cd26/menang-di-icsid-angkatmartabat-indonesia-di-dunia-internasional, diakses pada tanggal 2 Januari 2019.

23 Maria Yuniar Ardhiati, Gugatan Churchill Ditolak Arbitrase Indonesia Lolos Denda Rp 17 T, 9 Desember 2016, URL: https://katadata.co.id/berita/2016/12/09/gugatan-churchill-ditolak-arbitraseindonesia-lolos-denda-rp-17-t, diakses pada tanggal 2 Januari 2019.

24 Sentosa Sembiring, 2007, Hukum Investasi, Nuansa Aulia, Bandung, hlm. 180.

25 Lihat Pasal 2 Undang-Undang Nomor 5 Tahun 1968 tentang Persetujuan atas Konvensi tentang Penyelesaian Perselisihan Penanaman Modal antara Negara dengan Warga Negara Asing. 
antara ICSID dan Bank Dunia memberikan dampak terhadap biaya arbitrase yang lebih murah karena ICSID menerima subsidi yang diberikan oleh Bank Dunia.

Pelaksanaan persidangan lembaga Arbitrase ICSID dilakukan dalam kerangka hukum internasional sebagaimana yang telah ditetapkan dalam Konvensi ICSID serta regulasi dan aturan untuk proses pelaksanaan. ICSID sebagai suatu lembaga atau mekanisme dalam hal menyelesaikan sengketa memiliki yurisdiksi sendiri yang terlepas dari sistem-sistem yang dimiliki oleh hukum nasional suatu negara. Pengadilan nasional memiliki peran utama dalam hal memberikan kekuatan dan meningkatkan pengakuan atas eksekusi putusan yang telah dikeluarkan oleh ICSID. Apabila terdapat beberapa pihak yang memiliki sikap apatis dan tidak ingin menjadi bagian dalam persidangan, ICSID tentunya akan terus melakukan persidangannya dan mengeluarkan putusannya yang mana keputusannya tersebut masih diakui oleh negara-negara peratifikasi Konvensi Washington.

Putusan ICSID terkait sengketa kasus Churchill Mining dan Pemerintah Indonesia juga bersifat final dan mengikat. Sehingga harus dapat dilaksanakan karena para pihak merupakan negara yang sama-sama meratifikasi Konvensi New York 1958 tentang Pengakuan dan Pelaksanaan Keputusan Arbitrase Asing (the 1945 New York Convention on the Recognition and Enforcement of Foreign Arbitral Awards). Berdasarkan Konvensi tersebut, maka setiap negara yang menjadi anggota diharuskan untuk dapat memberikan pengakuan dan melaksanakan keputusan-keputusan yang diberikan oleh arbitrase yang dikeluarkan di negara lain yang juga menjadi negara anggota konvensi

\section{Kesimpulan}

Penanaman modal asing sebagai suatu kegiatan yang dilakukan oleh penanam modal asing baik oleh perorangan warga negara dan badan usaha asing, serta pemerintah asing dengan cara menanamkan modal yang menggunakan modal asing sepenuhnya atau berpatungan dengan penanam modal yang terdapat di dalam negeri untuk melakukan usaha di wilayah Indonesia. Penanaman modal asing bertujuan untuk mendapatkan laba melalui penciptaan suatu produksi atau jasa yang dilakukan pihak asing disuatu negara.

Putusan ICSID terkait sengketa kasus Churchill Mining dan Pemerintah Indonesia bersifat final dan mengikat sehingga harus dapat dilaksanakan karena para pihak merupakan negara yang sama-sama telah melakukan ratifikasi terhadap Konvensi New York 1958 tentang Pengakuan dan Pelaksanaan Keputusan Arbitrase Asing. Persidangan yang dilakukan oleh ICSID dilaksanakan dalam kerangka hukum internasional sebagaimana yang telah ditetapkan dalam Konvensi ICSID serta regulasi dan aturan yang dibentuk untuk proses pelaksanaannya. Lembaga Arbitrase didefinisikan sebagai badan yang dipilih oleh para pihak yang bersengketa untuk dapat memberikan putusan terhadap sengketa tertentu yang menjadi yurisdiksinya serta memberikan pendapat yang bersifat mengikat terhadap suatu hubungan hukum tertentu sebelum timbulnya sengketa sebagaimana yang terdapat dalam Pasal 1 angka 8 Undangundang No. 30 Tahun 1999 tentang Arbitrase dan Alternatif Penyelesaian Sengketa.

\section{Saran}

Pemerintah daerah perlu memperhatikan perizinan yang diberikan kepada para pihak atau investor asing yang ingin menanamkan modalnya agar tidak terjadi tumpang tindih perizinan dengan memperhatikan segala aspek, seperti lingkungan dan lain sebagainya. 
Pemerintah perlu mengadakan negosiasi ulang terkait status BIT yang merupakan perjanjian bilateral yang dibuat oleh Pemerintah Indonesia dengan beberapa negara lainnya. Hal tersebut disebabkan karena perjanjian akan terus menjadi ancaman bagi Pemerintah Indonesia jika tak direvisi.

\section{Daftar Pustaka}

\section{Buku}

AK, Syahmin. (2006). Hukum Kontrak Internasional. Jakarta: PT RajaGrafindo Persada.

Adolf, Huala (2012) Hukum Penyelesaian Sengketa Internasional. Jakarta: Sinar Grafika. , Huala. (2002). Arbitase Komersial Internasional, Jakarta: RajaGrafindo Persada.

Chandrawulan, An An (2011). Hukum Perusahaan Multinasional, Liberalisasi Hukum Perdagangan Internasional dan Hukum Penanaman Modal, Bandung: P.T. Alumni.

Fajar, Mukti dan Yulianto Achmad. (2010). Dualisme Penelitian Hukum Normatif $\mathcal{E}$ Empiris, Yogyakarta: Pustaka Pelajar.

Somarajah, M. (1994). The International Law on Foreign Investment, Cambridge: Cambridge U.P.

Sembiring, Sentosa. (2007). Hukum Investasi, Bandung: Nuansa Aulia.

Sumantoro.(1984). Bunga Rampai Permasalahan Penanaman Modal dan Pasar Modal, Bandung: Binacipta.

Widjaya, Albert. (1982). Impak Kegiatan Perusahaan Multinasional Terhadap Keadaan Sosial dan Politk di Indonesia, Bandung: Binacipta.

\section{Peraturan Perundang-Undangan dan Instrumen Internasional}

Kitab Undang-Undang Hukum Perdata.

Undang-Undang Nomor 5 Tahun 1968 tentang Persetujuan atas Konvensi tentang Penyelesaian Perselisihan Penanaman Modal antara Negara dengan Warga Negara Asing (Lembaran Negara No. 32 tahun 1968).

Undang-Undang Nomor 30 Tahun 1999 tentang Arbitrase dan Alternatif Penyelesaian Sengketa (Lembaran Negara Republik Indonesia Tahun 1999 Nomor 138, Tambahan Lembaran Negara Republik Indonesia Nomor 3872).

Undang-Undang Nomor 25 tahun 2007 tentang Penanaman Modal (Lembaran Negara Republik Indonesia Tahun 2007 Nomor 67, Tambahan Lembaran Negara Republik Indonesia Nomor 4724). 
Undang-Undang Nomor 4 Tahun 2009 tentang Pertambangan Mineral dan Batubara (Lembaran Negara Republik Indonesia Tahun 2009 Nomor 4, Tambahan Lembaran Negara Republik Indonesia Nomor 4959).

Konvensi New York 1958 tentang Pengakuan dan Pelaksanaan Putusan Arbitrase Asing (Conventionon Recognition and Enforcement of Foreign Arbitral Award).

Konvensi Washington 1965 tentang ICSID (Convention on the Settlement of Investment Disputes between States and National of Other States) United Nations-Treaty Series, No. 8359 .

\section{Karya Tulis Ilmiah}

Geraldi, Aldo Rico. (2017). Kompetensi Arbitrase Internasional Dan Pengadilan Nasional Terkait Penyelesaian Sengketa Penanaman Modal Asing. Jurnal Advokasi FH UNMAS, Vol. 7, No. 2.

Geraldi, Aldo Rico, (2017). Penyelesaian Sengketa Investasi Melalui International Centre For Settlement Of Investment Dispute (Studi Kasus Pemerintah Indonesia Vs Churchill Mining). Tanjungpura Law Journal, Vol. 1, Issue 2.

\section{Internet}

Artikel. Churchill vs Indonesia: Permintaan Perlindungan oleh Churchill Ditolak, 24 Desember 2014, URL : http://www.tambang.co.id/churchill-vs-indonesiapermintaan-perlindungan-oleh-churchill-ditolak-2516/ diakses pada tanggal 2 Januari 2019.

Antara News. Indonesia siapkan data pendukung hadapi gugatan, 15 Juni 2012, URL :http://www.antaranews.com/berita/316344/indonesia-siapkan-datapendukung-hadapi-gugatan- churchill, diakses pada tanggal 2 Januari 2019.

Dimas Jarot Bayu. RI Menang Gugatan Arbitrase Lawan Perusahaan Tambang Inggris dan Australia, $\quad 8$ Desember 2016, URL: https://nasional.kompas.com/read/2016/12/08/21210551/ri.menang.gugatan. arbitrase.lawan.perusahaan.tambang.inggris.dan.australia, diakses pada tanggal 2 Januari 2019.

Hasyry Agustin. Menang Di ICSID Angkat Martabat Indonesia Di Dunia Internasional, 10 Desember 2016, URL: https://www.hukumonline.com/berita/baca/lt584abeb00cd26/menang-diicsid-angkat-martabat-indonesia-di-dunia-internasional, diakses pada tanggal 2 Januari 2019.

Maria Yuniar Ardhiati. Gugatan Churchill Ditolak Arbitrase Indonesia Lolos Denda Rp 17 T, 9 Desember 2016, URL: https://katadata.co.id/berita/2016/12/09/gugatanchurchill-ditolak-arbitrase-indonesia-lolos-denda-rp-17-t, diakses pada tanggal 2 Januari 2019. 
Lusia Arumingtyas. Lawan Churchill Mining Indonesia Menang Gugatan Arbitrase Internasional, $\quad 10$ Desemebr 2016, URL: https://www.mongabay.co.id/2016/12/10/lawan-churchill-mining-indonesiamenang-gugatan-arbitrase-internasional, diakses pada tanggal 2 Januari 2019.

Rista Rama Dhany. Digugat Churchill Rp 20 T, Pemerintah RI Percaya Diri Menang, 26 Februari 2014,

URL

http:/ / finance.detik.com/read/2014/02/26/183143/2509500/1034/digugatchurchill-rp-20-t-pemerintah-ri-percaya-diri-menang, diakses pada tanggal 2 Januari 2019. 